\title{
Research on School-enterprise Cooperation Teaching of Accounting Under the Integration of Production and Education Based on Information Technology
}

\author{
Guirong Wang ${ }^{1, a}$, Sufen Wang ${ }^{2}$
}

\author{
${ }^{1}$ Qingdao Technical College, Qingdao, China \\ ${ }^{2}$ Shandong University of Finance and Economics, Jinan, China \\ awangguirong24680@163.com
}

\begin{abstract}
The development of Internet information technology provides more choices for modern teaching methods and modes. The teaching method of accounting major has changed greatly with the school-enterprise alliance model. This article introduces that under the Internet information technology, enterprises can provide students with a real training environment through distance education, while the school provides enterprises with flexible labor reserve resources. The school-enterprise joint accounting teaching shortens the distance between teaching and application through this combination of industry and academia, and achieves a win-win situation for all parties. Finally, appropriate suggestions and future research directions are put forward for the teaching method of the integration of production and education.
\end{abstract}

Keywords: Production and education integration; accounting; school-enterprise cooperation

\section{INTRODUCTION}

Accounting is mainly to study how to confirm accounting elements such as income and assets from the perspective of an enterprise as an accounting entity during the business cycle. As an enterprise's accounting staff, not only must have the ability to issue statements but also be able to completely record the various transactions of the enterprise. At the same time, it is more important to be able to provide users of accounting information with comprehensive and complete financial information, and to participate in the decision-making and management activities of major corporate matters, such as: mergers between enterprises, quality management, taxation strategies and information technology in the future In enterprise applications and other activities. Whether it is a large central enterprise, state-owned enterprise, or small private enterprise, there are accounting practitioners. A large number of accounting practitioners are active in the company, using their professional knowledge to study the movement of corporate funds, improve corporate economic news, save costs, and contribute to the development of the company $[1,2]$.
The fundamental task of the school is to cultivate talents, and teaching work is the central task. Therefore, improving the quality of teaching is an eternal theme, and the integration of production and education is an employment-oriented teaching reform that highlights skills and strengthens application. As far as the integration of production and education in the accounting major of higher vocational schools is concerned, the school actively develops accounting-related industries, closely integrates industry and teaching, and the two support and promote each other, and finally the school is set up as a collection of talent training, scientific research, and technology. Service is an industrial business entity that forms a school-running model that integrates schools and enterprises. Due to the particularity of the accounting profession, the actual situation of the current integration of industry and education is not balanced. Generally speaking, it is more prominent in improving the operating skills of accounting, strengthening the application of accounting theoretical knowledge, and school-enterprise cooperation [3, 4].

Therefore, vocational colleges, based on a profound understanding of the spirit of the report of the 19th National Congress of the Communist Party of China, have brainstormed and constantly explored. Based on the 
characteristics of higher vocational students, the training goals and characteristics of accounting professionals, and social needs, this article now combines the actual situation of the survey and puts forward specific suggestions on the integration of production and education, and school-enterprise cooperation in the accounting profession.

\section{CURRENT PRESSURES AND CHALLENGES FACING THE ACCOUNTING PROFESSION}

\subsection{The challenge of advanced network information technology to the accounting profession}

Since the rapid development of information technology in the 1960s, especially since the 1990s, under the impact of network information technology in various industries, the living environment and development environment have undergone earth-shaking changes. Especially for the accounting profession, it used to rely on traditional manual bookkeeping, accounting, and reimbursement, which required a lot of labor costs. With the development of network information, various types of software have emerged, information sharing has become more convenient, and the accounting, accounting, and reimbursement processes have been standardized. If you are proficient, it becomes an important part of the work of accountants.

\subsection{Challenges brought by changes in fiscal and taxation policies to the accounting profession}

An excellent financial worker should always pay attention to the country's fiscal and taxation policies in addition to strong professional knowledge, high personal morality, selflessness, and fearlessness. Only by grasping the changes in policies and making timely judgments and adjustments by the policies can the work be done smoothly and there will be no mistakes. For example, a series of fiscal and taxation policy changes. With the implementation of these policies, China's fiscal and taxation management system has undergone earthshaking changes. These changes have made important contributions to the formation of a reasonable and standardized government fiscal revenue pattern and the construction of a modern fiscal system. Every reform will be a new learning opportunity for accountants. Only by continuous and timely learning can we better understand policy changes, promote the growth of our professional knowledge, and make ourselves invincible.

\section{THE CERTAIN LAG IN ACCOUNTING EDUCATION}

\subsection{The lag of accounting teaching materials}

With the continuous changes and updates of accounting laws and regulations and other policy documents, our corresponding accounting professional teaching is also facing the impact of subsequent changes. Then, in the course setting and teaching process of the teaching content of accounting professional courses, we need not learn, to continuously learn and to update to adapt to these new policy changes. It is also necessary to timely reflect and reflect on the new trends and new directions of the reform of the accounting profession in the construction process. However, the reality is often that the compilation cycle of traditional textbooks is relatively long, and some new knowledge, new cases, and new technical methods cannot be reflected in the textbooks in time. This is closely related to the establishment of accounting professions, production, and construction. The actual requirements of service and management are not suitable, which affects the training and development of students' professional level. At the same time, some higher vocational colleges are accustomed to using teaching materials compiled by their professional teachers for teaching. The limitations are self-evident, and they cannot expand students' horizons.

\subsection{Teachers' level and understanding are lagging behind}

At present, in some colleges and universities, the level of teachers is somewhat lagging, especially the theoretical level of young teachers is very high. However, due to the lack of motivation for learning and insufficient ability to go deep into the enterprise, they cannot fully understand the current situation and development direction of the enterprise. In the teaching process, it is naturally impossible to pass the latest social skills and professional knowledge to students. At the same time, because teachers' teaching has always been carried out in the school, apart from the few daily pieces of training and summer on-the-job exercises, the activities of teachers at other times are limited to the school and cannot be well integrated into the enterprise. To understand the development of the enterprise and compare the problems that need to be improved in our teaching will lead to a significant lag in the overall professional level and understanding of teachers. To improve the professional level and understanding, it is necessary to study continuously and study again. 


\subsection{The training mode is lagging behind}

The accounting profession requires not only rich professional knowledge but also full hands-on ability. In China, in reality, there are more industrial enterprises. The talents needed by industrial enterprises are more inclined to hands-on ability. The talents recruited by industrial enterprises need to undergo simple 6-10 days of training after entering the enterprise. More colleges and universities only care about the training of professional skills, thus neglecting the implementation of practical operations. Broaden students' knowledge, strengthen the implementation of basic theoretical knowledge, and meanwhile allow students to participate more in business practice, learn in practice, practice in learning, and make full use of the "learning + practice" training model to break out of the existing stereotypes.

\section{ANALYSIS IN THE INTEGRATION OF Production AND EduCATION AND THE COOPERATION}

The accounting positions of enterprises have their particularities, and with the popularization of accounting computerization, the needs of many enterprises for accounting positions have also undergone great changes. This has led to the fact that accounting students can obtain internship opportunities related to accounting.

\subsection{Lack of motivation for business-to-school business cooperation}

Enterprises seek to maximize their interests and are unwilling to pay for school-enterprise cooperation. In addition, the government does not reduce or exempt the educational surcharges of enterprises. Therefore, enterprises lack enthusiasm for school-enterprise cooperation and it is impossible to be proactive and willing to cultivate for the society. Skilled talents.

\subsection{Enterprises do not need batch financial personnel}

Small businesses generally adopt the agency bookkeeping method. Even if the company has an independent financial department, it does not need or time to train talents for society; and with the popularization of artificial intelligence, what companies need now is management accounting talents.

\subsection{The problem of university teachers}

Some so-called "dual-qualified" teachers only have various certificates and are not qualified for practical teaching work; second, the age structure of teachers is not reasonable, and echelon construction needs to be done Optimization; Third, although older teachers are rich in teaching experience, they are insufficient in using advanced teaching equipment and various financial software, and their knowledge is not updated in time.

\section{SUGGESTIONS AND PROPOSAL}

The innovation and reform of the training model of accounting professionals in higher vocational colleges must be guided by the reform of educational thinking and educational concepts. Educational administrative departments at all levels, higher vocational colleges, and accounting schools and departments must combine production and education integration, new situations, new problems, new situations in school-enterprise cooperation, and conduct discussions on educational ideas and concepts to promote problems.

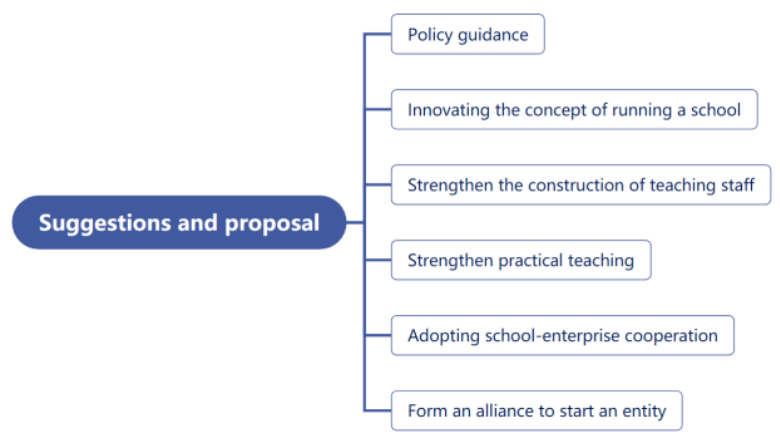

Figure 1. The potential suggestions and proposal

\subsection{Policy guidance}

The government promulgated and implemented policies and used policies to encourage companies to voluntarily cultivate skilled talents for the society. For example, reward companies based on the number of students received and trained and the length of time; companies are allowed to be taxed as management expenses; The tax system recognizes the local education fee surcharge or reduction or exemption of education fee surcharge according to the cost of the integration; certain policy preferences are given to enterprises.

\subsection{Innovating the concept of running a school}

Initially, not only emphasize the importance of practical teaching and increase the proportion of practical classroom teaching and practical training, but also actively develop accounting-related industries, such as using the existing school The advantages of venue and professional talents establish agency bookkeeping centers, financial consulting centers, entrepreneurial incubation bases, etc., and then closely integrate industry and teaching, design and complete teaching tasks according to the actual work projects of the enterprise, and finally form a school and enterprise integrated school model; secondly, we should not only emphasize skills 
training, and promote the reform concepts of quality education; third, because now higher vocational education not only offers specialist education,

Besides, it has begun to implement the training model of higher vocational, higher vocational undergraduate, and higher vocational graduate students. Therefore, in the higher vocational stage, the school should consider enabling its students to have a certain sustainable development ability and lay a solid foundation for their promotion after graduation, so they must teach under their aptitude; The fourth is to implement the " $1+\mathrm{X}$ " certification system. When accounting students graduate, they can get both the diploma and the junior professional qualification certificate.

\subsection{Strengthen the construction of teaching staff}

To improve the quality of teaching and realize the integration of production and education, we must first strengthen the training of "dual-professional" teachers, which is a necessary condition for schools to achieve connotative development; first, the government has introduced a system that is conducive to schoolenterprise cooperation, such as appropriate reduction or exemption of education fees In addition, at the same time, further increase investment, so that more teachers have the opportunity to participate in skills training and internship; second, higher vocational colleges should implement a "five-year cycle" comprehensive teacher training system, mainly using modern technology to teach The third is to actively recruit part-time teachers from enterprises and institutions through schoolenterprise cooperation; fourth, the government revises the professional title review documents to completely change the status quo of the "four only" and guide high Vocational teachers are on the right path to cultivate high-quality professional and technical personnel for the society.

\subsection{Strengthen practical teaching}

The survey found that there is still a way to go before highlighting the status of practical teaching. The specific manifestations are: first, there are still many accounting schools that have not established and implemented a relatively independent practical teaching system; second, some accounting teachers are still used to being too dependent Theoretical teaching arbitrarily squeezes the practical teaching time in the teaching plan; third, the software and hardware equipment of the school laboratory needs to be updated; fourth, the experimental training teachers cannot guarantee the need. According to the characteristics of the accounting profession, it is equipped with sufficient experimental training teachers, open the experimental training room, encourage and provide students with experimental training opportunities as much as possible. Companies can use site resources to set up a fiscal and tax incubation base, which provides students with practical training positions for understanding internships and follow-up internships. Use the extracurricular time to educate and have fun, such as effectively organizing poker games on accounting subjects to help students correctly understand economic and business activities for accounting.

\subsection{Adopting school-enterprise cooperation in the style of introducing companies into schools}

The school provides free office space to financial and taxation companies such as agency bookkeeping centers, accounting firms, and accounting training centers. Accountants of the financial and taxation companies provide students with actual accounting information and practical guidance. Generally, agency bookkeeping companies have taken over the bookkeeping business of many small companies. They have recruited multiple accountants to replace the company for accounting. Students learn the bookkeeping vouchers that have been booked by the agency bookkeeping center, and they don't understand or do something wrong. You can consult an accountant in time. Besides, teachers can also work part-time in the above-mentioned companies, which can not only help enterprises conduct financial accounting research and development but also help teachers improve practical ability.

\subsection{Form an alliance to start an entity}

For example, the school-school alliance, because general higher vocational colleges have accounting majors, and the courses offered are similar, so you can form alliances to learn from each other's strengths or form a joint force to enhance your strength. For example, a certain number of certified public accountants is required to open an accounting firm, while the number of certified public accountants in higher vocational colleges is limited, so they can jointly apply. Besides, a schoolenterprise alliance can also be used. The school has formed alliances with agency bookkeeping centers, financial consulting centers, and various companies to actively raise teaching funds through multiple channels and make full use of social education resources to serve school education and teaching. 


\section{THE NEW DIRECTION OF INDUSTRY- EDUCATION INTEGRATION AND SCHOOL- ENTERPRISE COOPERATION}

\subsection{Returning to students and reconstructing the learning embodiment that students can accept}

Many higher vocational majors do not highlight this point in the curriculum settings. For example, the accounting professional curriculum does not return to students well, and it is difficult to choose the curriculum and teaching materials. Accounting professional title examination courses, accounting foundation, elementary accounting practice, intermediate accounting practice, and intermediate financial management courses. Many high-level accounting majors neglect the foundation of students when setting up courses, and combine intermediate accounting practice and intermediate financial management. This kind, of course, requires a certain basic knowledge of accounting to learn well and set it in, while in the basic courses of accounting basics and elementary accounting practice, the lesson time is streamlined. The previous basic courses have not been studied well, and students will be very strenuous when they study intermediate accounting practice and intermediate financial management courses. They cannot understand the class. To run a student-centered university with learners as the center, we must truly understand what students are thinking and what students need, starting from students, serving students, researching students, and forming a student outlook. The goal of cultivating accounting professionals in higher vocational colleges is also to train applied-skilled talents.

\subsection{Optimization of joint teaching between school teachers and corporate teachers}

On the one hand, fully impart professional knowledge to students, on the other hand, use their own social practical experience to lead students to understand the company and society, and integrate the knowledge they have learned with the needs of the company. Therefore, strengthening the training of "dual-qualified" teachers is an indispensable part of the process of integration of production and education and schoolenterprise cooperation.

\subsection{Universities and enterprises communicate and jointly explore new models of talent training}

The cultivation of talents is not only the responsibility of universities. In the process of schoolenterprise cooperation, to make the talents cultivated by universities fully meet the needs of enterprises, universities and enterprises must work together to explore new models of talent training. In the process of talent training, universities and enterprises may wish to start from the different perspectives of students, society and universities, jointly formulate a reasonable curriculum system, and jointly explore new talent training models under the background of the rapid development of network information technology and changing fiscal and tax policies. To cultivate students' comprehensive professional quality, job skills, and employment competitiveness, making full use of the two different educational environments and educational resources of schools and enterprises, using key enterprises as the main base for cooperation, exploring the talent training model and new school-enterprise cooperation Measures, to do a good job of linking up talent training goals and the role of industry guidance, forming a high-quality, high-skilled education model.

\section{CONCLUSION}

Overall, the development of an enterprise is inseparable from the development of management. As a management major, the development of the accounting profession is inseparable from school-enterprise cooperation. Let students' knowledge and talents be fully utilized in schools and enterprises, and make the best use of their talents. Only in this way can we achieve real school-enterprise cooperation, determine the new direction of talent training, keep up with the new environment changes in talent training, and continuously improve our talent training goals and models, to cultivate the skills that are truly suitable for the development of the new era. Only with type and compound talents can we change the shortage of talents and employment difficulties in China.

\section{REFERENCES}

[1] Junzheng, and $\mathrm{Wu}$. "Exploration and Practice of the New Model of School-enterprise and ProductionEducation Cooperation under the Big Data Era." 2018.

[2] Sun, Mei, C. Zhang, and C. Xie. "Application Strategies of "Industry-Education Integration and School-Enterprise Cooperation" Model in Mechanical Specialty."

[3] Ma, Lixin, and P. Yuan. "Research on SchoolEnterprise Cooperation Mode Innovation Based on Integration of Industry and Education." Proceedings of the 2018 5th International Conference on Education, Management, Arts, Economics and Social Science (ICEMAESS 2018) 2018.

[4] Chen, and Yuting. "Study on the Cultivation Mode of Accounting Talents in School-enterprise Cooperation." 2018. 